\title{
SEEING SCENIC NEW ZEALAND: W. W. SMITH'S EYE AND THE SCENERY PRESERVATION COMMISSION, 1904-06
}

MICHAEL ROCHE

\section{Abstract}

The passage of the Scenery Preservation Act 1903 was intended to once and for all protect the last scenic areas of New Zealand as reserves. To this end, a commission was appointed to undertake the task of inspecting sites and making recommendations. Its members included W. W. Smith, a Scottish-born and trained gardener, accomplished amateur natural historian and ethnologist. Smith's ideas about scenery illustrate in microcosm how settler society came to see New Zealand as scenic, but in ways that amended British sensibilities in a new landscape.

Keywords: scenery, New Zealand, W. W. Smith

\section{Introduction}

In a major effort to once and for all time preserve the remaining, threatened scenic areas of New Zealand, parliament passed the Scenery Preservation Act 1903 and established a Scenery Preservation Commission to inspect and recommend lands for gazetting as Scenic Reserves. ${ }^{1}$ Chaired by Stephenson Percy Smith (a retired Surveyor General), its members were J. W. A. Marchant (Surveyor General), Henry Matthews (government forester), Major Hone Tunuiarangi (a Ngati Kahungunu chief and Native Land Court assessor) and W. W. Smith (Curator of the Ashburton

1 Tony Nightingale and Paul Dingwall, Our picturesque heritage: 100 years of scenery preservation in New Zealand (Wellington: Science \& Research Unit, Department of Conservation, 2003). 
Domain, a local public park with gardens and recreation grounds). It had the powers of a commission of inquiry, which reflected Premier R. J. ('King Dick') Seddon's characteristic desire to get things done quickly and boldly. ${ }^{2}$

This article explores Smith's engagement with the New Zealand environment as one of the commissioners, in order to see how he used, later modified, and then augmented European conventions for expressing and constructing beauty in nature in New Zealand. It does not focus directly on the achievements of the Scenery Preservation Commission, which have in any case been examined by Tony Nightingale and Paul Dingwall, while Percy Smith has been criticised by the historian Geoff Park for seeking to appropriate Māori land. Park does, however, credit Percy Smith with having a well-developed sense of the picturesque. ${ }^{3}$ As well as exploring forest remnants, these being much reduced by the turn of the twentieth century as pastoral farming expanded, the commission also inspected other landscape elements, such as lakes, waterfalls and rivers as potential scenic reserves, and Māori pa sites-fortified earthworks originally with palisades_-as possible historic reserves. These last features Smith termed 'medieval Maori castles'.

As such, this paper is one of a pair, the other of which considered how Smith inscribed British scenic landscape features into the gardens he established and how he made use of panoramas and vistas in the Ashburton Domain. ${ }^{5}$ A 'reading the landscape' approach was necessary in the earlier paper because of the paucity of written material in which Smith explained which landscapes were scenic and why. Fortunately, the domain could be thought of as a miniature landscape which, if studied carefully, provides some clues as to which assemblages of nature that he found scenic. This is in diametric contrast to the situation when Smith served as Secretary of the Scenery Preservation Commission, the subject of this current paper. In this capacity, Smith wrote voluminously about landscapes from across the whole of the country which he considered to be scenic, some of which were later protected as Scenic Reserves.

\footnotetext{
2 Indeed, in 1906, he abruptly wound it up on the grounds that it was taking far too long to complete its work. Percy Smith was frustrated that the commission was so perfunctorily terminated when it had all but completed its task and he declared himself 'much aggrieved by the rudeness and peremptory tone' of the telegram (Stephenson Percy Smith, Reminiscences of a Pioneer Surveyor, Historic Document Series No. 5 (Wellington: Treaty of Waitangi Research Unit, Stout Research Centre, Victoria University, 2011 [original typescript 1916]), 22). Seddon had not expected the task to be so large nor that the commissioners would be so thorough and time-consuming in their inspections. In any case, a commission of inquiry was not the appropriate administrative vehicle for such a lengthy task, which led in 1906 to a legislative amendment that established a Scenery Preservation Board, comprised entirely of officials, to create further reserves.

3 Nightingale and Dingwall, Our picturesque heritage and Geoff Park, Ngä Uruora = The Groves of Life: Ecology and History in a New Zealand Landscape (Wellington: Victoria University Press, 1995).

4 Loose papers in bound volume MS 046/1 163/1 M4/1/2 Smith William Walter, Puke Ariki, New Plymouth.

5 Michael Roche, 'W. W. Smith and the Transformation of the Ashburton Domain "from a wilderness into a beauty spot", 1894 to 1904', Studies in the History of Gardens and Designed Landscapes 36 (2016): 65-77, doi.org /10.1080/14601176.2015.1056481.
} 
This present paper looks at how Smith saw 'scenery' in early twentieth-century New Zealand. The two papers are further connected in that some of the scenic features that Smith found attractive in the New Zealand landscape were prefigured in his work in the Ashburton Domain. This in itself is not unexpected-he brought a bundle of landscape preferences with him from Britain, sharpened by his training as a gardener-but what is of interest are the ways in which he turned his Britishtrained eye onto the New Zealand landscape, and how quite rapidly some of his ideas about what constituted scenery changed. ${ }^{6}$ This reconstituted appreciation of scenery is not in itself unique and is found in many other settler states, but what is valuable in this instance is that Smith's correspondence enables it to be tracked in some detail. His ideas are emblematic of wider changes in settler society regarding local scenery, though because of his training and work as an estate gardener, he expressed them with a precision and deftness not captured by lay commentators. New Zealand efforts at scenery preservation and national-park creation were also comparatively early compared to other countries, further justifying attention to Smith's writings.

Rapid and extensive environmental change has been a recurrent theme in writing about the environmental history of New Zealand. ${ }^{7}$ Local researchers have also pursued the theme of environmental transformation through biographical treatments of specific figures. These range from Ross Galbreath's book-length treatment of the ornithologist Sir Walter Buller, The Reluctant Conservationist, to Paul Star's thesis on the nineteenth-century farmer-politician Thomas Potts (and his articles in this issue and in the 2015 volume), an early champion of forest conservation, to Graeme Wynn's study of Herbert Guthrie-Smith, owner of the Tutira sheep station and author of the difficult-to-categorise farm biography of the same name, to James Beattie's study of the painter Alfred Sharpe and his coming to terms with New Zealand scenery, and my own exploration of the public servant, amateur botanist, and subsequent head of the New Zealand State Forest Service, Edward Phillips Turner's sense of a forest consciousness in New Zealand. ${ }^{8}$ Potts, Buller, GuthrieSmith and Smith also had ornithological interests. Sharpe and Guthrie-Smith aside, the others had political or public service roles, and most were from the upper echelons of colonial society.

6 Later on this had a strong influence on his planting efforts as Curator at Pukekura Park in New Plymouth from 1908 to 1920 .

7 Kenneth Cumberland, 'A Century's Change: Natural to Cultural Vegetation in New Zealand', Geographical Review 31 (1941): 529-54, doi.org/10.2307/210498; Alfred Crosby, Ecological imperialism: The biological expansion of Europe, 900-1900 (Cambridge: Cambridge University Press, 1986); Tom Brooking and Eric Pawson, eds., Seeds of Empire: The Environmental Transformation of New Zealand (London: I. B. Tauris, 2011); Eric Pawson and Tom Brooking, eds., Making a new land: Environmental histories of New Zealand (Dunedin: Otago University Press, 2013). 8 Ross Galbreath, Walter Buller: The reluctant conservationist ([Wellington]: GP Books, 1989); Paul Star, 'T. H. Potts and the origins of conservation in New Zealand (1850-1890)' (MA diss., University of Otago, 1991); Graeme Wynn, 'Remapping Tutira: Contours in the environmental history of New Zealand', Journal of Historical Geography 23 (1997): 418-46, doi.org/10.1006/jhge.1997.0061; Beattie, 'Alfred Sharpe's Forest Consciousness'; and Michael Roche, 'Edward Phillips Turner: The development a "Forest Consciousness" in New Zealand 1890s to 1930s', in Proceedings of the 6th National Conference of the Australian Forest History Society Inc., ed. Michael Calver (Rotterdam: Millpress, 2005). 
Smith, in contrast, was very much the working-class man, albeit one with specialist training as a gardener and impressive credentials a naturalist. ${ }^{9}$ For most of his career Smith was employed as a gardener and park curator, apart from his time on the Scenery Preservation Commission. He was also particularly active from the 1890 s to the 1900s, although earlier he had procured bird specimens for Buller. ${ }^{10}$ Smith merits attention because he was not part of the colonial elite, but his training had provided him with the lexicon to describe scenery with some consistency and precision, and to articulate a sense of beauty in the landscape where others might have struggled to render what they saw into words. Smith, by background and training, was somewhat apart from the university-educated Scots who the historian David Young saw as exerting an influence on conservation efforts in nineteenth-century New Zealand out of proportion to their numbers, so in part, this paper also answers his call for more research on this phenomenon. ${ }^{11}$ Brad Patterson et al. dissent from Young's 'green Scots' view in favour of a range of responses in transforming as well as preserving and conserving the landscape characterised by 'ambiguity' rather than a straightforward binary between 'conservationists' and 'improvers'. ${ }^{12}$

Early British settlers saw the New Zealand landscape as having both familiar and exotic elements. An analysis of pre-1850 settler diaries undertaken by Paul Shepard identified two exotic features - the forest and the Màori pa_-as 'aspects of the New Zealand scene in particular [that] became aesthetic through picturesque vision'; that is, in terms of British landscape canons. ${ }^{13}$ According to Star, by the late nineteenth century the indigenous flora and fauna had also become 'a strong component of national identity' in New Zealand. ${ }^{14}$ This association was accentuated by the awareness of the plant and animal life being highly endemic, and was manifest in the early attempts to preserve some of the flora and fauna in national parks and scenic reserves in which mountains, forests, waterfalls and fern gullies were favoured features. The historian Sir Keith Sinclair had anticipated something of Star's position in identifying the early use of ferns, indigenous birds and the Southern Cross constellation as symbols whereby 'native-born' New Zealanders sought to differentiate themselves, not from the empire but from simply being 'British'. ${ }^{15}$

9 Gardener does not translate that adequately into the early twenty-first century—today Smith would be more adequately described as a landscape architect.

10 Michael Roche, "W. W. Smith (1852-1942)_ "Second to none in the Dominion as a Field naturalist" (Paper presented to the New Zealand Polymath Colenso and his Contemporaries Conference, Victoria University, Wellington, 16-18 November 2016).

11 David Young, Our Islands, Our Selves: A History of Conservation in New Zealand (Dunedin: Otago University Press, 2004), 68-72.

12 Brad Patterson, Tom Brooking, and Jim McAloon, Unpacking the Kists: The Scots in New Zealand (Montreal: McGill-Queens University Press, 2013), 164.

13 Paul Shepard, English Reaction to the New Zealand Landscape before 1850. Pacific Viewpoint Monograph no. 4 (Wellington: Department of Geography, Victoria University, 1969), 14.

14 Paul Star, 'Native Bird Protection, National identity and the Rise of Preservation in New Zealand to 1914', New Zealand Journal of History 36 (2002): 123.

15 Keith Sinclair, A Destiny Apart: New Zealand's Search for National Identity (Wellington: Allen \& Unwin in association with Port Nicholson Press, 1986). 
The situation remained complicated, however, and early- to mid-twentieth century New Zealand domestic gardens continued to combine British design and functions with the use of selected indigenous plants, suggestive of the complex links between their use in gardens and as emergent signifiers of national identity. ${ }^{16}$

The work of the Scenery Preservation Commission prepared the way for establishing 'scenic reserves' in the early twentieth century as latter-day extensions of the concern for the picturesque, in which forest and pa remained important constituent parts of the aesthetic vision. At the time, scenic reserves were loosely regarded as national parks in miniature. They were a subset of a suite of reserves that the geographer Franklin Ginn, echoing Shepard, Star and Sinclair, described as 'the pragmatic and romantic reaction of the settler', producing 'containment that aimed to preserve the remnants for posterity and as a mark of colonial difference'. ${ }^{17}$ Smith is an ideal protagonist through which to explore both Ginn's abstractions in the form of 'romantic reaction' and on-the-ground efforts at 'containment', as exemplified by his work on the Scenery Preservation Commission.

\section{W. W. Smith, FES (1852-1942), gardener and naturalist}

Born in Hawick in the Scottish Borders, Smith, who served his time as an apprentice gardener in Scotland, worked at various estates, including Rose Hill, Carlisle, where he was Henry Lonsdale's under-gardener in 1871. From 1872 to 1874 he was at Burley-on-the-Hill near Oakham, Rutland, the residence of the local MP George Henry Finch. ${ }^{18}$ In 1875, he migrated to New Zealand, with excellent references, working industriously as a gardener on J. B. Acland's isolated Mount Peel Station in Canterbury. ${ }^{19}$ Thereafter, he worked as a gardener on several other estates, spent over a year at Lake Brunner and some months in Australia, before returning to Canterbury. ${ }^{20}$ As time permitted he travelled widely through the forest areas in the foothills of the Canterbury Plains. During this period he developed an impressive

\footnotetext{
16 Helen Leach, 'Exotic natives and contrived wild gardens: the twentieth-century home garden', in Environmental Histories of New Zealand, ed. Tom Brooking and Eric Pawson (Melbourne: Oxford University Press, 2002), 214-29; Helen Leach, 'Native plants and National Identity in New Zealand Gardening: An Historical Review', Horticulture in New Zealand 5 (1994): 28-33.

17 Franklin Ginn, 'Extension, subversion, containment: eco-nationalism and (post)colonial nature in Aotearoa New Zealand', Transactions of the Institute of British Geographers, n.s. 33, no. 3 (2008): 347.

18 Elsewhere, I have mistakenly claimed that Smith was on the gardening staff of the famous Burghley Estate, itself made over by Capability Brown in the late eighteenth century. I am grateful to Dr Ross Galbreath for correcting me on this point.

19 As 'skilled in practical geometry and in the laying out of grounds and in every sense of the word a very intelligent young man': William Temple [Head Gardener], 9 December 1874. Correspondence 1870 - Dec 1920 ARC 1-163/2 Smith W.W. M4/1/2 Smith Papers, Puke Ariki, New Plymouth.

20 The position of gardener in the private sector did not have the same security, standing or career path about it in New Zealand as in Britain, e.g. A. J., 'Emigration to New Zealand', Gardeners Chronicle 41 (1907): 308.
} 
record as a natural historian and was eventually described as 'a field naturalist second to none in the Dominion in the accuracy and thoroughness of his observations'. ${ }^{21}$ In 1903, he published the first scientific account of invasive species in Ashburton County in the Transactions and Proceedings of the New Zealand Institute. ${ }^{22} \mathrm{He}$ was also a foundation member of the Polynesian Society, established in 1892 'to promote the study of the Anthropology, Ethnology, Philology, History and Antiquities of the Polynesian races'. ${ }^{23}$

In 1894, Smith found a more secure position as Curator of the 90 -acre (36 ha) domain in the South Island country town of Ashburton. He worked diligently in transforming the domain into a parkland-like setting with European, Australian and North American trees, some formal flower gardens, and several lakes to create panoramas, vistas and picturesque scenes that were very much derivative of his British training and described with local pride as 'the beauty spot of the country'. ${ }^{24}$ He was acknowledged as 'a man of exceptional taste and resource'. ${ }^{25}$ Smith never really wrote about the canons of his work as a landscape gardener or about what constituted scenic beauty, but his legacy remains in the present-day Ashburton Domain and Pukekura Park in New Plymouth. ${ }^{26}$

The curatorship was not well paid, and in 1904 Smith resigned to sit on the newly formed Scenery Preservation Commission, his appointment having been recommended by the local MP. ${ }^{27}$ Initially Smith had declined to take the post, but he changed his mind with the offer of a permanent position in the Forestry Branch of the Lands Department once the commission's work was completed. ${ }^{28}$ His departure sparked some lamentations. One newspaper letter-writer ventured: '[as] one who has seen the Ashburton domain grow from a wilderness into a beauty spot I feel sorry ... we are losing Mr W. W. Smith'. ${ }^{29}$

\footnotetext{
21 'Naturalist's Death', Evening Post, 6 March 1942. See also Roche, W. W. Smith (1852-1942)—'Second to none in the Dominion as a Field naturalist'.

22 W. W. Smith, 'Plants naturalised in the County of Ashburton', Transactions and Proceedings of the New Zealand Institute 36 (1903): 203-25.

23 Journal of the Polynesian Society, 1 (1892): 5-6. Smith's name is not included amongst the members listed in the 1892 first issue, but in later years when the list includes the year of membership, his is given as 1892.

24 Ashburton Guardian, 12 March 1904.

25 Ashburton Guardian, 26 February 1903.

26 Michael Roche, 'Transforming the Colonial Settlement with Parks \& Domains: Scenic Beauty in two New Zealand Towns 1894 to 1920', in Proceedings of the $11^{\text {th }}$ Urban History / Planning History Conference, ed. Andrea Gaynor, A. Gralton, J. Gregory, and S. McQuade (Perth: State Library of Western Australia, University of Western Australia, 2012), 293-305.

27 Minister to McLachlan, undated [1903]. TO 153 1904/191/1 Scenery Preservation Commission Appointment of Commission, Archives New Zealand, Wellington. McLachlan was an opposition MP.

28 Seddon to Smith (telegram) 5 March 1904. ARC 1-163/2 Smith William Walter M4/1/2 Puke Ariki, New Plymouth.

29 Ashburton Guardian, 12 March 1904
} 


\section{The Scenery Preservation Commission, 1904-06}

Smith's appointment was a sign of the esteem in which he was held. He was only one of many domain curators in the country, residing in a comparatively small rural town, but his eye for beauty in landscapes was acknowledged and he independently had a considerable reputation as a natural historian with interests in ethnography. But there were other pre-existing connections that assisted his appointment. In 1902, Premier Seddon had visited the Ashburton Domain, praising it fulsomely for his local audience, and likely was introduced to Smith. ${ }^{30}$ Smith had been known to Percy Smith through the Polynesian Society since 1892, and in 1903 had corresponded with him about damage done to state forests, urging government action to conserve them for utilitarian and scenic purposes. ${ }^{31}$ Percy Smith, in turn, forwarded a copy of Smith's letter to Marchant, the Surveyor General, at a time of some accelerated government action about scenery preservation. ${ }^{32}$ In addition to Seddon's own recollections of Ashburton Domain, Marchant may have recalled Smith's interest in forest conservation and scenery.

The records of the Scenery Preservation Commission provide abundant evidence of Smith's aesthetic response to specific landscapes. He was appointed its secretary, so that the minute books include his own synopses of site visits. These are doubly useful in that they contain not only descriptions of areas considered to be 'scenic' but also other sites that did not meet the criteria for protection. It might be argued that as secretary he was merely summarising the reactions of several of the commissioners to scenic areas, so his minutes are an amalgam of views rather than just his own. This is a valid point, though in most of the cases quoted here, Smith was reporting on solo trips and the evaluation was his own, even if it was shared by the other commissioners. In any case, his considerable commission correspondence reveals what are indisputably his responses to the landscape. This was so, for instance, when he wrote of the 'charming sylvan scenery' surrounding the Raumanga Stream near Whangarei and its 'series of exceptionally picturesque rapids and waterfalls all typical of many of the lovely streams flowing through the primeval forests of the North'. ${ }^{33}$ In fact, sometimes considerable sections of the minutes describing potential scenic reserves repeat verbatim sentences and paragraphs from Smith's other correspondence, which gives additional veracity to the view that the opinions about the scenic beauty of sites from the minute books relating to forests, waterfalls, rivers and lakes are essentially his own. Smith after all was able to provide an eye trained

\footnotetext{
30 Ashburton Guardian, 13 November 1902.

31 W. W. Smith to S. Percy Smith, 11 August 1903. LS1 51887/84 Straight Number Series, Archives New Zealand, Wellington.

32 Michael Roche, 'Securing Representative Areas of New Zealand's Environment: Some Historical and Design Perspectives', New Zealand Geographer 37 (1981): 73-7, doi.org/10.1111/j.1745-7939.1981.tb00955.x.

33 W. W. Smith to Superintendent of the Tourist Department, 27 November 1904. TO 153 1904/191/11 Movement of Scenery Preservation Commission, Archives New Zealand, Wellington.
} 
in British landscape aesthetics which complemented the botanical and horticultural expertise of Matthews, Percy Smith's geographical, historical, and ethnographical knowledge about much of the country, and Tunuiarangi's deep understanding of Māori lore, custom and land.

\section{Smith and the commission at work}

The five members of the commission initially moved en masse to inspect areas, but at 65 years of age and after many years of field surveying work in the bush under arduous conditions, Percy Smith early in 1905 declared he was unable to continue and asked to be relieved of his duties. ${ }^{34} \mathrm{~A}$ compromise arrangement was reached whereby the other commissioners would carry out the field inspections and they would all meet to prepare their recommendations. Smith, as the only effective fulltime member of the commission, though sometimes in the company of Matthews or Tunuiarangi, was sent off to explore and report on potential scenic reserves.

The commissioners held seven meetings, some lasting several days, at a number of cities and towns in order to consider 381 recommended sites, all at a cost somewhat in excess of $£ 7,000 .{ }^{35}$ By 1906,61 areas, totalling 14,565 acres (5,894 ha), had been gazetted as scenic reserves under the Scenery Preservation Act 1903. ${ }^{36}$ These reserves were to become the foundations of New Zealand's flora and fauna preservation system. A thematic rather than chronological or regional approach is adopted hereafter in order to accentuate what Smith regarded as scenic in the New Zealand landscape.

\section{Forests, streams and lakes}

With his gardening expertise and natural history interests, Smith viewed the New Zealand forest, known colloquially as 'the bush', in a combination of both scenic and botanical frames of reference, moderated by some emotive responses.

He did not hesitate, with respect to the last, to point to the larger 'cost' of burning off, a favoured method of settler land development, as for instance when he visited Mount Hikurangi in Northland and noted that

\footnotetext{
34 Percy Smith, Reminiscences of a Pioneer Surveyor, 222.

35 These 381 included a large number of potential historical reserves in Marlborough associated with Cook's visits. 'Scenery Preservation', Appendices to the Journals of the House of Representatives [hereafter AJHR] (Wellington: Government Printer, 1906), C-6.

36 Scenery Preservation Report, 1907, AJHR C-6, 5. This rather underplays the extent of the commission's work, for another 76,721 acres $[31,047 \mathrm{ha}]$ were reserved under other legislation.
} 
[t]his magnificent and once bush-clad mountain has been despoiled of its sylvan beauty by the ravages of fire which has left it a bleak and barren relic of the heartless work of the Pakehas. ${ }^{37}$ The scenic surroundings of the village of Hikurangi are unspeakably barren. Though the hills show their softly and smoothly rounded tops the cold demeanour of the whole district as viewed from the Railway Station can only create feelings of regret and sadness in every lover of scenic nature. ${ }^{38}$

The 'heartless work' ${ }^{39}$ can be summarised by a few statistics: forest cover, at 54 per cent of land area in 1840 when New Zealand became a British colony, had been reduced to around 25 per cent by about $1900 .{ }^{40}$ Much of this deforestation had occurred since the 1890s as part of government closer land-settlement policy. A number of forest-dwelling indigenous bird species became extinct through this process. ${ }^{41}$ In the North Island, closer land settlement involved the purchase of Māori land for resale to land-hungry pākehā small farmers. Refrigeration technology in the 1880s gave New Zealand farmers access to the British market for meat, butter, and cheese; stimulated the expansion of the pastoral frontier into the forested North Island hill country; and turned New Zealand into one of Britain's 'imperial farms'. ${ }^{42}$ Around the same time, the forest came to be seen no longer as a barrier to settlement and inexhaustible in extent but instead was viewed by more progressive settlers as being under threat, and with scenic attributes that made portions of it worth saving. One manifestation of this, on the larger scale, was the creation of Tongariro National Park in 1887, which was followed by five other parks, mostly under separate acts of parliament, amounting to 2.75 million acres (1.11 million ha)

37 A term to describe New Zealanders of European descent. Its etymology is not completely certain, nor has its use always been taken as flattering, but Smith's deployment of the term is not out of keeping for the time.

389 July 1904, Scenery Preservation Commission Minute Books, April 1904 to Nov. 1905. LS 70 1/1, Archives New Zealand, Wellington. Smith was not alone in this regard; a number of settlers expressed in poetry a lament for the destruction caused by clearing the forest for farmland. One of the more notable was the journalist and Liberal MP W. P. Reeves, whose 'The Passing of the Forest', originally written in 1898, ended with the memorable verse:

The axe bites deep. The rushing fire streams bright;

Swift, beautiful and fierce it speeds for Man,

Nature's rough-handed foeman, keen to smite

And mar the loveliness of ages. Scan

The blackened forest ruined in a night,

The sylvan Parthenon that God will plan

But builds not twice. Ah, bitter price to pay

For Man's dominion-beauty swept away!

39 This was not the majority viewpoint-Thomas Kelly, a Taranaki newspaper proprietor and MP, in 1877 in the New Zealand Country Journal more typically declared that 'bush felling is a noble work; there the effort of colonisation is more palpably displayed than perhaps in any other mode of utilising waste lands. It is literally carving a home in the wilderness'. See also Graeme Wynn, 'Destruction under the guise of improvement', in Making a New Land, ed. Pawson and Brooking, 112-38.

40 Cumberland, 'A Century's Change', 531.

41 Smith himself is credited with making the last authenticated sighting of a pair of Huia (Heteralocha acutirostris) at Mount Holdsworth in the Wairapara in 1907 (Evening Post, 8 June 1929).

42 Brooking and Pawson, Seeds of Empire. 
by $1906 .{ }^{43}$ The Scenery Preservation Commission, in comparison, was working on the micro-scale, though ranging countrywide (and, unlike national park creation, it was not so focused on alpine environments).

In northern New Zealand, while inspecting the Whangarei bush by himself, Smith was interested in the indigenous tree species, but found little that commanded his attention. Land settlement had already begun in the vicinity and this alone made it difficult to justify purchasing the area for scenery preservation:

The park-like flat on which the area of Totara is growing is close to a farm residence and would probably cost a considerable sum to acquire. The terraced banks of the river and the flats above them have up till lately been a rich forest in which grew Ratas, Kahikatea, Tairare, Puriries, Pungas, and Nikaus of immense size but all are now rapidly vanishing. ${ }^{44}$

The use of 'park-like' is important. Here, Smith employs a term from the gardening lexicon that he brought with him to New Zealand, where 'park' in Scottish usage referred to 'an enclosed farm ground or field'..$^{45}$ Smith recurrently comments on the 'typicality' of the forest types and readily lists the tree species, without exception using their indigenous names, even though he was familiar with their botanical nomenclature. Shortly prior to the establishment of the commission, after pressure from MPs, the Lands and Survey Department had agreed to reserve representative areas of the forest types of the colony for scientific purposes. ${ }^{46}$ Traces of this imperative percolated through to the efforts of the Scenery Preservation Commission, so that forests that were 'typical' of districts were inspected, albeit they were to be scenic remnants of the typical forest and thus potentially were not necessarily that representative of the district.

Not only the forest, but also the various waterbodies of the colony attracted the attention of Smith and the other commissioners. Approaching Queenstown in 1905, he wrote of Allens Creek ${ }^{47}$ that it was:

43 Tongariro, 1887; Hooker, 1890; Tasman, 1897 (with Hooker the basis of Mt Cook National Park); Egmont, 1900; Bealy, 1901 (the basis of Arthur's Pass National Park); Sounds, 1905 (the basis of Fiordland National Park). AJHR 1906, C-6.

4420 July 1904, Scenery Preservation Commission Minute Books April 1904 to Nov. 1905. LS 70 1/1, Archives New Zealand, Wellington. Smith refers to various species only by their Māori names, even though he was well aware of their botanical names, though in present-day usage you would not add the 's' to make them plural, e.g. Rata not Ratas. Nikau (Rhopalostylis sapida) is a palm endemic to New Zealand.

45 Michael Symes, A Glossary of Garden History (Princess Risborough: Shire Publications, 2006), 91

46 Real momentum for the protection of representative areas was achieved only in the 1970s when it was informed by ecological surveys that revealed the considerable extent to which alpine ecosystems were vastly overrepresented in the national protected areas system. See Roche, 'Securing Representative Areas'.

47 'Creek' was not used here in its more precise English definition of a waterway that runs into the sea and is subject to tidal flows, but rather as a synonym for 'stream'. 
a very beautiful narrow wooded and rocky gorge opening onto the great Kingston moraine and distant from the railway about half a mile from which it presents beautiful scenery to the otherwise bare plain and almost barren rocks in the vicinity. On the south entrance to the valley the high rugged rocks though sparsely intermixed with light bush and scrubby growth are conspicuous and interesting from their numerous and peculiar laminations. ${ }^{48}$

'Beautiful' has an everyday meaning, but here Smith seems to have been employing the word more specifically to refer to landscapes 'of smooth undulating appearance, with no harshness, surprise or broken lines'. ${ }^{49}$ Where the creek narrowed, he recorded that, 'The huge moss[-] covered rocks lying in the bed of the creek are very beautiful and the water here forms a series of small waterfalls and rapids adding greatly to the picturesque character of the valley'. ${ }^{50}$ His use of 'picturesque' is in the late-eighteenth-century sense, as applied to the landscapes of the English Lake District (where Smith had for a time resided), of 'broken, irregular, varied and often spectacular' scenery. The term cannot but have been carefully chosen. ${ }^{51}$

Lakes were part of the British landscape gardening tradition and at the Ashburton Domain, Smith had applied considerable energy to introducing wildfowl and planting the islands and lake margins. Naturally formed lakes also captured the commissioners' attention, but not always favourably. In February 1905, Smith was sent alone to inspect Lake George near Invercargill. He reported that:

[ $\mathrm{t}$ ] he lake is surrounded by sphagnum swamp and a dense luxuriant growth of rushes. After the more valuable timber was removed from the neighbourhood of the lake some years ago the remaining vegetation was burned which remains in unsightly masses over most of the plain on which the lake is situated and could not be described as being beautiful. The water of the lake is almost black while the bracken and sedgy margin is covered with masses of burnt and floating wood. ${ }^{52}$

The impact of gold-mining, fuelled by the Victorian concerns for progress and improvement, had destroyed the pristine and potentially scenic qualities of the lake. Smith did concede, however, that in future, '[a]s the decaying vegetation disappears from around the lake the land will probably become drier when the shores

486 May 1905, Scenery Preservation Commission Minute Books April 1904 to Nov. 1905. LS 70 1/1, Archives New Zealand, Wellington.

49 Symes, A Glossary of Garden History, 19.

506 May 1905, Scenery Preservation Commission Minute Books April 1904 to Nov. 1905. LS 70 1/1, Archives New Zealand, Wellington.

51 Symes, A Glossary of Garden History, 97.

5225 February 1904, Scenery Preservation Commission Minute Books, April 1904 to Nov. 1905. LS 70 1/1, Archives New Zealand, Wellington. 
could provide a camping, picnicking and boating resort'.$^{53}$ On other occasions, for instance, when inspecting Lake Horowhenua near Levin (which had been admired by settlers a generation earlier), ${ }^{54}$ he was more favourably impressed:

A careful inspection was made of the scenic features of the lake and several good photographs were taken of the more striking and beautiful scenic views of the lake and the areas of native bush remaining at the top end of the lake are in an excellent state of preservation..$^{55}$

Here, one of his criteria for 'scenic' comes through: that the forest surrounding the lake was in good condition; that is, undamaged by the felling of timber, by grazing, or wind damage. ${ }^{56}$

\section{Landscapes, waterfalls and rock features}

Waterfalls were also inspected as possible scenic reserves. Early on in 1904, the entire commission viewed the Tangoio Falls in Hawke's Bay, noting with satisfaction that 'the falls are situated in a picturesque hilly bush-clad gully with the bush remaining in perfect preservation' ${ }^{57}$ Smith described it more fully at the time of inspection as:

about 70 feet $[21 \mathrm{~m}]$ in height with a perpendicular face of rock-the water falling into a magnificent large deep basin. The semi circular rocky sides are richly clothed in ferns and other semi aquatic plants which are kept constantly wet with the spray of the falls. The valley for a distance of three quarters of a mile $[1,200 \mathrm{~m}]$ is bush-clad and beautiful and adds greatly to the pleasure of tourists travelling to or from Napier to Gisborne. ${ }^{58}$

Smith again used the term 'picturesque' to describe the scene and he wrote with some feeling about other waterfalls that he inspected. For instance, of the Whangarei Falls in Northland he recorded in the minutes:

[t] he falls are conveniently sited within 2 minutes' walk of the main road. Their height is about 60 feet [18 $\mathrm{m}$ ] and [they] have formed a very large[,] deep, and ornamental basin beneath them which is fringed on the rocky ledges around it with a rich growth

5324 February 1905, Scenery Preservation Commission Minute Books, April 1904 to Nov. 1905. LS 70 1/1, Archives New Zealand, Wellington.

54 Leslie Adkin, Horowhenua (Wellington: Department of Internal Affairs, 1948), 160.

554 May 1906, Scenery Preservation Commission Minute Books, Archives New Zealand, Wellington.

56 The implication was that it was in 'pristine' condition, but this in fact was not the case, for the district had long been occupied by Māori and the lake was an important food source. Some nine villages and fortified pa had at one time or another been built on its shore, in addition to six pa on artificial islands in the lake (Adkin, Horowhenua). 5725 May 1904, Scenery Preservation Commission Minute Books April 1904 to Nov. 1905. LS 70 1/1, Archives New Zealand, Wellington.

58 ARC 1 163/1 Smith W.W. M4/1/2 MS 046/1 Bound Volume, Puke Ariki, New Plymouth. 
of ferns and other plants generally occurring in such situations. Beneath the falls a beautiful forest glade extends down the valley with the dominant trees of several species overhanging the rocky stream. ${ }^{59}$

But ever practical, he also noted that their permanent protection would require the acquisition of a strip of land five chains $(100 \mathrm{~m})$ wide either side of the stream and extending $10-12$ chains $(200-240 \mathrm{~m})$ below the falls. The 'forest glade' also has a specific meaning as a 'clearing in the woods', but the vegetation forms that he was applying this to were not familiar 'home' conifers or deciduous tree species. ${ }^{60}$ Contemporary postcard images of the falls support Smith's description and show how he was now applying 'picturesque' to landscapes resplendent with tree ferns that were somewhat different from the original British usage (Figure 1). He was now seeing new sorts of picturesque landscapes particular to New Zealand.

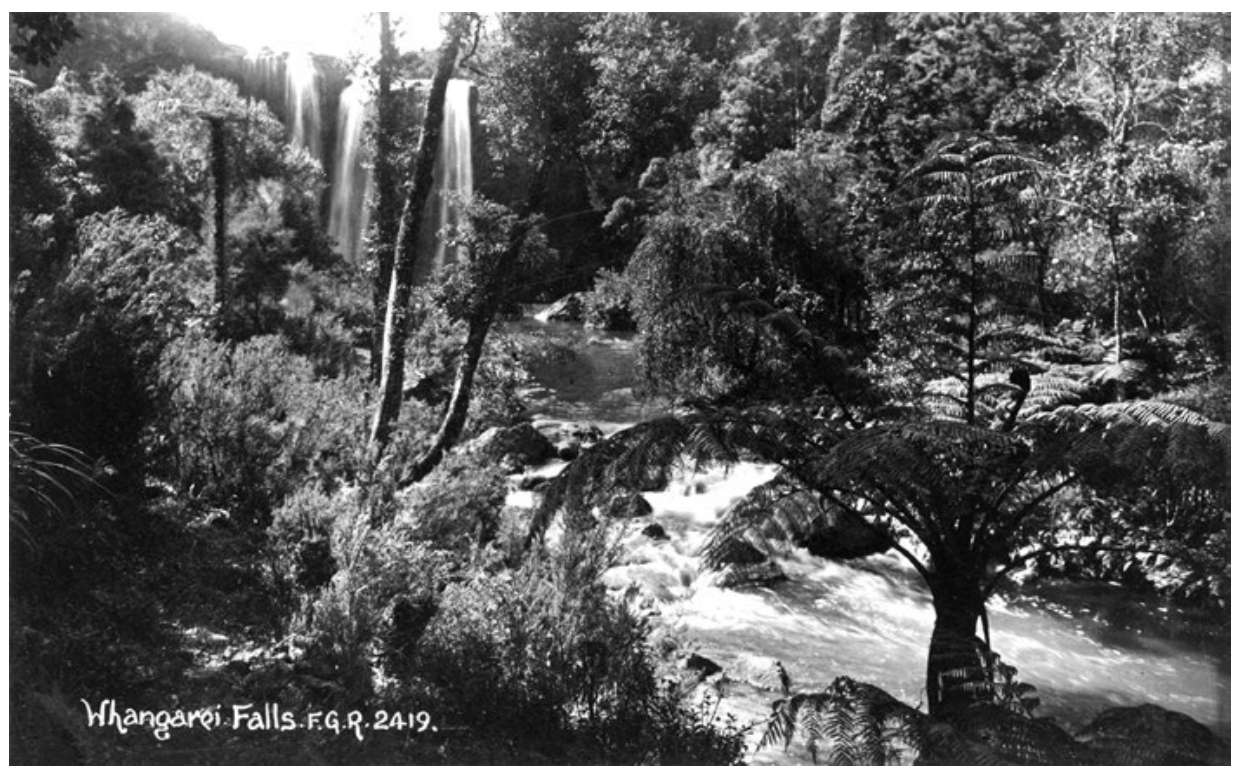

Figure 1: Whangarei Falls, which Smith described as having, 'a very large deep ornamental basin' and a 'beautiful forest glade'.

Source: This image was taken by photographer F. G. Rawlings possible before the area was reserved. The card was not posted. Photo: Author's Collection.

In reporting on scenic areas in Northland, Smith also made the more utilitarian point that a day trip from the Springs Hotel would enable visitors to see the Whangarei Falls, the Kamo Springs, typical native bush, and several old pa sites. ${ }^{61}$

596 July 1904, Scenery Preservation Commission Minute Books, April 1904 to Nov. 1905. LS 70 1/1 Archives New Zealand, Wellington.

60 Symes, A Glossary of Garden History, 59.

61 Smith to Superintendent, Tourist Department, 27 November 1905. TO 153 1904/191/11 Movement of Scenery Preservation Commission, Archives New Zealand, Wellington. 
On other occasions, Smith wrote about particular features in the context of the surrounding landscapes. Of the remote Routeburn track, beyond the northern end of Lake Wakatipu in the South Island, which had attracted tourists since the 1880s, he wrote:

The numerous large waterfalls of the Routeburn and the luxuriant sub-alpine vegetation occurring on the meadows below Lake Harris and the Saddle should add greater value to the Routeburn as a tourist route to Martins Bay and the magnificent scenery viewed from the Harris Pass on the Dividing Range has probably no equal in the South Island. After a careful and complete inspection of the Routeburn I can only report it as being in perfect condition and worthy of permanent preservation as a scenic route. ${ }^{62}$

One area that he described in terms of its broader landscape was the North Island hill country near Hunterville. This land was cleared of forest by settlers under the Liberal government's closer land-settlement programme of the 1890s to 1910s, the same government that had in response to persistent lobbying by one of its urban MPs, Harry Ell, set up the Scenery Preservation Commission.

The gorge of the former is a charming scenic valley about a mile in length and is mainly clad in native bush. Much of the long narrow gorge consists of precipitous $\mathrm{papa}^{63}$ cliffs with here and there rich masses of ferns clothing their faces and having at their bottoms a wealth of mixed native trees and dense undergrowth. The larger trees comprise Rimu, Miro, Kahikatea, Titoki, Mairie, Drymis, ${ }^{64}$ Matai, and Totara. Much of the undergrowth is comprised of [sic] beautiful tree-ferns belonging to two species, other species of native fern are also abundant. On ascending the crown of the hill after turning out of the gorge a magnificent view is obtained of the valley extending to the Turakino [Turakina] River. At the head of the gorge there is a beautiful waterfall about 80 feet $[24 \mathrm{~m}]$ in height with a deep circular basin. There could be no more suitable or beautiful an area obtainable for scenic purposes or to illustrate a charming New Zealand river gorge. ${ }^{65}$

The scene comprises various indigenous tree and fern species, but the assemblage of vegetation, landforms, waterfall and river to Smith constituted a New Zealand scene that he now saw as both beautiful and typical.

6210 April 1905, Scenery Preservation Commission Minute Books April 1904 to Nov. 1905. LS 70 1/1, Archives New Zealand, Wellington. Smith's judgment has been borne out by events; today the $32 \mathrm{~km}$ track links two national parks that are part of a World Heritage area.

63 'Papa' is the local name for the soft mudstone characteristic of the wider region.

64 Now classified as Pseudowinteras dandy and often found in thickets after forest clearance, which further reinforces the point that some scenes that Smith saw as unmodified were actually much more altered than he appreciated.

6511 May 1904, Scenery Preservation Commission Minute Books April 1904 to Nov. 1905. LS 70 1/1, Archives New Zealand, Wellington. 
Smith's response to the black-sand beach of Piha on the Waitakere Coast west of Auckland was similar. Having travelled there on horseback specifically to inspect the bay and the Pohutukawa ${ }^{66}$ bush flanking it, he deemed it to be

wildly picturesque and its general scenic features viewed from any of the high overlooking hills with its high rugged and wave worn rocks with the breakers crashing unceasingly against them the bay is understandably one of the most magnificent seascapes in New Zealand. The bush clothing the slopes opening onto the Bay is of mixed character and very vigorous and contains large numbers of well grown Pohutukawa trees which must be charming when displaying their wealth of scarlet flowers during the summer months. ... magnificent trees, ferns and Nikau palms rising from stately feet abound. In fine weather the route we followed offers one of the best for pleasure seekers and lovers of nature in the Auckland province. ${ }^{67}$

Scenic beauty at this site, in Smith's view, emerged in part out of the vegetation, particularly the composition and the attributes of the trees, in terms of the height and architecture of the species as well as the colour of their flowers. The botanist and ecologist Leonard Cockayne in 1908 made some superficially similar arguments in his reports on Tongariro National Park and Waipoua kauri forest. ${ }^{68}$

Although forest and water were major constituent parts of Smith's construction of scenery, they were not the only ones; other natural geological features were also inspected. Among them, the limestone rock formations at Kamo, near Whangarei in Northland (Figure 2), are of interest because of the way in which he reported on them, and help answer a bigger question about the exactitude with which Smith used British gardening landscape terms. Smith wrote of the area as 'well known for its grotesque rocks'. ${ }^{69}$ The term 'grotesque' was actually used here in a very precise way. In period architectural vocabulary, it referred to a carved stone figure, but was also used to refer to strange, distorted, and ugly shapes, and thus was well suited to

66 Pohutukawa (Metrosideros excelsa), the red-flowering 'New Zealand Christmas tree', so called because it flowers in December. It naturally grew only on coastal locations in the northern half of the North Island.

6725 June 1904, Scenery Preservation Commission Minute Books April 1904 to Nov. 1905, LS 70 1/1, Archives New Zealand, Wellington.

68 In his botanical report on Tongariro, Cockyane wrote of the endemic nature of the New Zealand flora, commenting that 'the more special the vegetation the more distinctive the scenery' (Report on a botanical survey of the Tongariro National Park, AJHR C-11 [1908]). The plant formations of Waipoua he described as 'rare, beautiful, and at the same time [internationally] scientifically interesting' and 'of great beauty and scientific interest' (Report on a botanical survey of the Waipoua Kauri Forest, AJHR C-14 [1908], 2 and 31), but ultimately, in my assessment, Cockayne was being very instrumental about the nature of beauty, whereas for Smith the whole was greater than the sum of the 'plants', to misquote the aphorism. In addition, Cockayne was searching for a justification for the preservation for scientific reasons of the vegetation of New Zealand in national parks and reserves and made an appeal for their preservation because the scientific was also scenic, which he would have realised had greater chance of success. Cockayne's comments also highlighted a difference between the National Parks and scenic reserves; the former were preserving rare vegetation formations, but with regard to the latter Smith was looking for 'typical', i.e. representative, vegetation types that were also scenic.

6927 November 1904, TO 153 1904/191/11, Archives New Zealand, Wellington. 
describe the limestone formations. Smith was using terms from the British landscape gardening tradition with some precision and presumably this carries across to his use of other terms such as 'picturesque'.

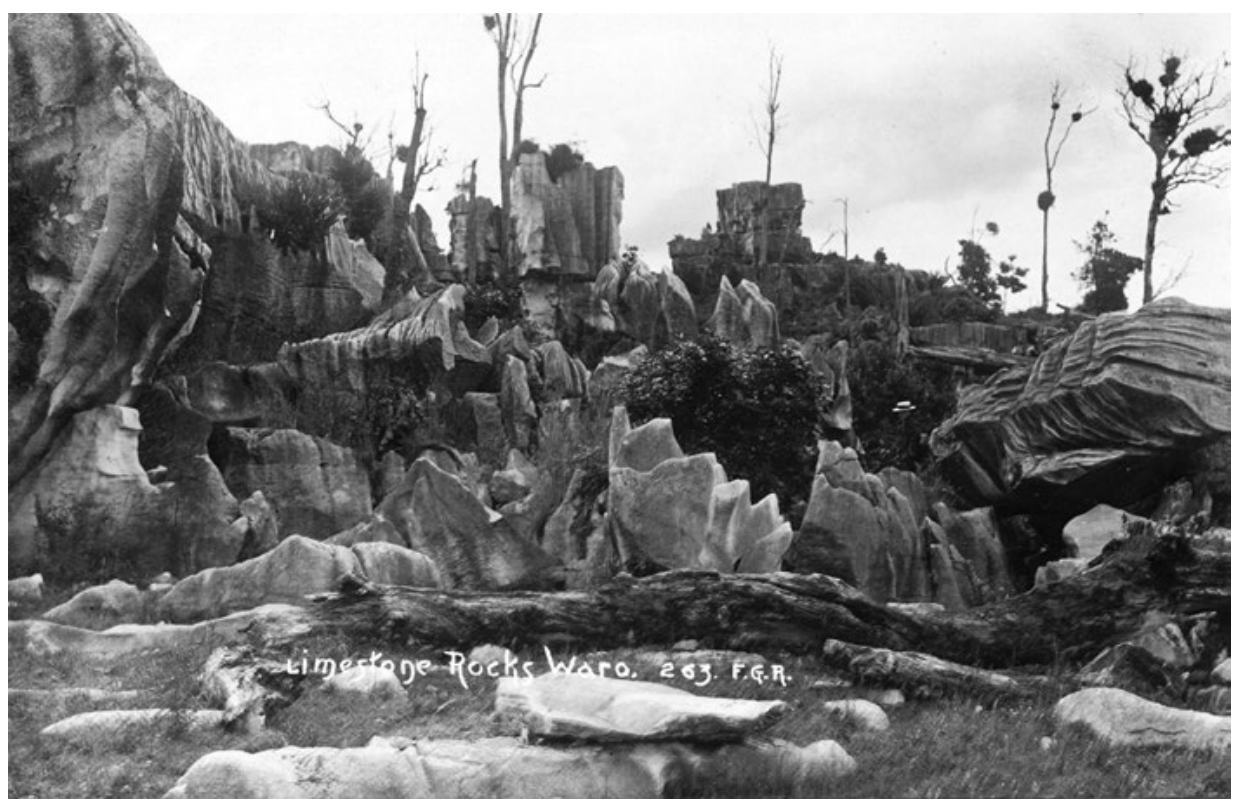

Figure 2: The 'Abbey' the 'grotesque and picturesque' limestone rocks that Smith inspected at Kamo near Whangarei in Northland. Light conditions made photography difficult and Smith and Matthews had to return the next day in order to successfully take photographs.

Source: This image taken by photographer F. G. Rawlings most likely dates from after the feature was reserved. The card was also not posted. Photo: Author's collection.

\section{Māori pa}

The commissioners' brief included the inspection of historic sites such as Māori pa; fortified villages with earthworks account for a disproportionately large amount of space in the minutes. The minute books also signal, however, that Māori landowners were not passively waiting to surrender land to the commissioners as they passed through the country. At the village of Ohinemutu, adjacent to the town of Rotorua, the commissioners met with chiefs and the local Māori Council to discuss the purchase of two well-known springs, but their efforts were deftly foiled: 
The native gentlemen explained that they had full sympathy with the work of the Scenery Commission but owing to the unsatisfactory position of the several claimants to the ownership of the springs they could give no definite information of these at present. ${ }^{70}$

The land they inspected at Ohinemutu also included two old fighting pa, Pukeroa and Rakekohunga, now used as 'uropa' (burial site). ${ }^{71}$ This meant that should the spring be acquired, 'the native owners would probably object to this uropa being included in the area'. ${ }^{72}$ If the landowners had not made this point, Tunuiarangi would have, and even Percy Smith would have understood well enough that this land would not be for sale.

Some Māori were quick to protest about the unwelcome impact of compulsory acquisition of their land for scenic reserves under the Public Works Act. The Liberal Government since the 1890s had purchased much Māori land to facilitate its closer land-settlement programme, ${ }^{73}$ and now some of the remaining lands would be lost to the settler state, on the grounds that it, and not the owners, was best able to preserve the scenery. ${ }^{74}$ This is another part of the larger paradox whereby the settler state was encouraging deforestation and expanding pastoral farming and then later trying to save remnant forests that had survived this process. Hapeta Hautehoro had earlier petitioned the government, complaining to this effect in 1903. The official response was that compulsory purchase could also apply to land owned by settlers, though it was conceded that 'the bulk of the scenic spots and historic reserves, especially in the North Island[,] are either Native owned or Native reserves'. ${ }^{75}$ Officials claimed that they had opted not to purchase large blocks of Māori land as this would create 'landless Natives', and proposed to pay the small sums for land purchase directly to the Māori owners rather than to the Public Trustee. Park disputed this position, and is

\footnotetext{
7010 September 1904, Scenery Preservation Commission Minute Books April 1904 to Nov. 1905. LS 70 1/1, Archives New Zealand, Wellington.

71 The preferred contemporary spelling is urupā. From the late nineteenth century, Māori developed Europeanstyle cemeteries, termed urupā. These Māori burial grounds were considered sacred (tapu) places.

7210 September 1904, Scenery Preservation Commission Minute Books, April 1904 to Nov. 1905. LS 70 1/1, Archives New Zealand, Wellington.

73 Tom Brooking, "'Bursting up” the Greatest Estate of All: Liberal Maori Land Policy, 1891-1911', New Zealand Journal of History 26 (1992): 78-98.

74 For example, the manner in which scenic reserves along the Mokau River were established. See Park, Ngä Uruora $=$ The Groves of Life, 145-50. Park does not discuss successful Māori efforts to rebuff the commissioners, as at Ohinemuri.

75 Robinson to Minister for Tourism \& Health Resorts, 13 October 1904. TO 1904/191/12, Archives New Zealand, Wellington.
} 
especially critical of Percy Smith and the commission for targeting scenery on Māori land. ${ }^{76}$ There were exceptions, however: Smith and Tuniarangi met with a 'Maori lady' in Pahiatua in order to visit an historic site she sought to 'present to the government'. ${ }^{77}$

Smith described other pa sites as excellent examples of 'old time Māori' settlements. Te Aute $\mathrm{Pa}$ in Hawke's Bay he described as 'now considerably dilapidated by sheep and cattle running over it, but it is a fine specimen illustrating the finely and perfectly terraced style of an ancient pa'. ${ }^{78}$ Smith was also aware that some of the places they inspected were linked to traditional legends, for instance Pekehana, a spring which featured in Sir George Grey's Polynesian Mythology. ${ }^{79}$ Not all the pa they visited were associated with a distant and romanticised Māori past; in 1904 Percy Smith, who had been in Taranaki during the New Zealand Wars of the 1860s, recounted how government troops had captured Te Arai Pa from the Hau Hau. ${ }^{80}$

Smith's appreciation of the historic Māori element in the New Zealand landscape was the subject of a lengthy article for the New Zealand Times, drawing on his commission work. Of the Wairarapa region, he wrote 'lovers of old-time Maori lore may enjoy opportunities of visiting several sites of old fortified pas and kaingas [villages] around Onake [Onoke] Lake' [Lake Ferry], but he easily moved into a mythic past observing that Lake 'Pounui which is said to be still haunted by a Taniwha, is charmingly situated'. ${ }^{81}$

76 Geoff Park, Theatre Country: Essays on Landscape \& Whenua (Wellington: Victoria University Press, 2006), 134. In my assessment, Park has conflated the efforts of the Scenery Preservation Commission and the later Scenery Preservation Board, and in highlighting how the 1910 amendment Act made Māori land vulnerable for gazetting as scenic reserves, he does not really discuss how the earlier 1906 amendment Act had specifically excluded Māori land from the provisions of the Act.

77 W. W. Smith to Superintendent, Tourist Department, 12 July 1905. TO 153 1904/191/11 Movement of the Scenery Preservation Commission, Archives New Zealand, Wellington. This, on a much smaller scale, parallels Te Heuheu's strategy of protecting the sacred volcanos of Ruapehu, Ngauruhoe, and Tongariro by 'gifting' them to the Crown for preservation in perpetuity as a park and to prevent them from ever being claimed by other tribes or by pākehā settlers. This was the basis of the Tongariro National Park in 1887. David Thom (1987) discussed the leadup to the gifting, while Richard Boast explains how the Crown actually had to purchase parts of the mountain. See David Thom, Heritage: The Parks of the People (Auckland: Lansdowne Press, 1987) and Richard Boast, 'Two block case studies Ruapehu-Tongariro and Tutira', in Buying the Land, Selling the Land: Governments and Maori Land in the North Island 1865-1921, ed. Richard Boast (Wellington: Victoria University Press, 2008), 341-72.

7826 May 1904, Scenery Preservation Commission Minute Books, April 1904 to Nov. 1905. LS 70 1/1, Archives New Zealand, Wellington.

7910 August 1904, Scenery Preservation Commission Minute Books, April 1904 to Nov. 1905. LS 70 1/1, Archives New Zealand, Wellington.

8010 August 1904, Scenery Preservation Commission Minute Books, April 1904 to Nov. 1905. LS 70 1/1, Archives New Zealand, Wellington. The Hau Hau was a branch of a Māori religious movement that originated in Taranaki. The Hau Hau believed Māori would regain land lost to the pākehā in the process of colonisation, and fought against the colonial troops in the New Zealand wars.

81 W. W. Smith, 'The Wairarapa as a Holiday Resort', New Zealand Times, 26 May 1906. Taniwha are supernatural creatures of various, sometimes changing, forms, broadly equivalent to dragons and serpents in other cultures, often living in water and seen as part of the natural environment in a traditional Māori world view. B. Keane, 'Taniwha', Te Ara-The Encyclopedia of New Zealand, updated 25 September 2011, www.Teara.govt.nz/en/taniwha. 


\section{Discussion}

The composition of the commission and Smith's expertise gave him a central role in defining 'scenic' New Zealand by designating actual scenic reserves on the ground. In his capacity as secretary of the commission, he left a quite detailed record, not only of the features and areas he regarded as scenic and worthy of permanent protection, but also of others that were not, by being to some extent despoiled by settlement. Ideas drawn from his formal training as a gardener in Britain and use of a gardening landscape vocabulary, particularly with regard to the picturesque, informed his views about what was 'scenic'. His letters and minutes thus provide an insight into the attitudes and ideas of an individual who played an important role in what Ginn describes as a 'pragmatic and romantic reaction' that within three years 'contained' over 77,000 acres for scenic preservation. ${ }^{82}$ While it is not possible to be totally confident that Smith's terminology was exactly the same as that of the garden historian Michael Symes, there is a considerable degree of alignment between Smith's descriptions and Symes' standard British garden history definitions, and period photographic images of some of the features concerned. But it is also possible to see how Smith came to see assemblages of the indigenous vegetation that would not have been so described in Britain as picturesque. Smith also neatly straddles the improver/conservationist borderland referred to by Patterson et al.; as a gardener he was involved in the transformation of the New Zealand landscape, while his Scenery Preservation Commission duties involved him in conservation, albeit of a largely preservationist type. Aligning myself more with Patterson et al. than Young, I would argue that it was Smith's training as a gardener rather than his being Scottish that was more decisive when it comes to appreciating how he saw scenery in New Zealand.

The work of the commission to preserve the scenic areas of the colony combined a desire to protect remnant and threatened areas with an awareness of the increasing importance of tourism, hence the effort given to creating reserves alongside the main trunk railway and the banks of the Whanganui River. ${ }^{83}$ Smith's assessment of scenery thus combined aesthetic arguments with more utilitarian dimensions. A range of natural and cultural features were recommended for preservation, though forest remnants predominated, while the cultural features were largely old Māori pa, along with some other sites of importance to the settler population, for instance Captain Cook's landing places.

82 Ginn, 'Extension, subversion, containment', 347.

83 Margaret McClure, The Wonder Country: Making New Zealand Tourism (Auckland: Auckland University Press, 2004). 
Smith eventually began making use of some additional terms of his own which were not part of his original garden lexicon as he looked more closely at the New Zealand landscape. He gave weight to what he described as 'typical' pa sites; he was also searching for 'authenticity', 'age' and 'completeness' in both the scenic and historic features to be secured as scenic reserves. Smith regarded the Mãori as ancient inhabitants; the many pa were remnants of a great past, which he imbued with medieval rather than classical associations, and the settler state, looking forward, was protecting these historic sites for posterity. There is a considerable synergy here with the arguments in favour of scenery preservation, where the intent was to preserve a scenic remnant of ancient vegetation which was otherwise being modified by both settler agriculture and invasive species. ${ }^{84}$

Forest remnants featured prominently in the list of recommended reserves. Smith's appreciation of their scenic qualities was expressed through canonical concepts such as the picturesque, but was not restricted to them. There were also botanical and regional considerations in Smith's scenic preferences. He recurrently comments on the 'typicality' of the forest types and readily lists the tree species. He also factored the 'age' and 'completeness' of the vegetation into his scenic assessment. The commission had been asked to select representative forest types as well as scenic areas, though the two tended to be conflated, with the latter taking precedence. More significantly, Smith was able to transgress the boundaries of science and mythology, moving easily between Western botanical knowledge and Māori traditions relating to various species. Ironically and possibly unknown to him, given the weight Smith gave to the age and completeness of the forest, some of the forest scenery that he so appreciated was neither old nor intact, having been modified much earlier by Māori burning and long-standing occupation of some areas.

Smith's lexicon for understanding and appreciating scenery included some standard sorts of British landscape garden referents such as 'beauty', 'picturesque', and 'grotesque', which were consistent with his training, and to some extent are writ small in the Ashburton Domain landscape he created prior to joining the Scenery Preservation Commission. Mountainous features and 'ancient Māori' pa, though, have no antecedents in the Ashburton Domain. Furthermore, as his encounter with the New Zealand landscape deepened, he developed a new terminology to allow him to explain why some sites were 'scenic' and worthy of preservation.

84 The point must be stressed, however, that Smith was never amongst those who believed that a weaker indigenous vegetation was falling back in the face of superior invading European species. He considered indigenous plants easier to grow than popularly imagined and distributed indigenous seed widely for use in home gardens. See also Ross Galbreath, 'Displacement, Conservation and Customary Use of Native Plants and Animals in New Zealand', New Zealand Journal of History 36 (2002): 36-50. 
Smith took the view that New Zealand had an ancient past remembered in Māori tradition, which ought to be preserved in the landscape. The ease, unusual amongst pākehā settlers, with which he could transgress the boundaries between botanical science and Māori lore, was notable.

Smith's later efforts as Curator of Pukekura Park from 1908 to 1920 further demonstrate that his ideas about scenery were not static. At Pukekura, while he continued to use some European landscape canons, he carried them out with local species as well as departing from these conventions to create a dense indigenous 'natural forest' in an urban park setting. ${ }^{85}$ A latter generation would engage more fully with the indigenous flora in domestic gardens as New Zealand moved from 'colony to nation'. ${ }^{86}$

\section{Conclusion}

Smith's work as Secretary of the Scenery Preservation Commission enables the nature of 'scenery' in New Zealand in the early twentieth century to be explored at a fine-grained level of analysis. It shows how he brought British ideas of the picturesque to New Zealand, how these enabled him to identify scenic areas for preservation as scenic reserves, and how eventually he was able to develop some additional terminology to explain what was scenic about the New Zealand forest. In so doing, he also somewhat reshaped his original notions of the picturesque in their application to New Zealand. His 'eye' was extremely influential in shaping the list of reserves recommended by the Scenery Preservation Commission. Though there are dimensions specific to this story, there are elements that are shared by other settler societies.

85 Roche, 'Transforming the Colonial Settlement', 293-305. While it might be argued that he is merely reproducing what Symes would term a thicket, a group of closely planted trees forming a wilderness where the latter was defined as an informal woodland of mixed species, in the context of his work on the Scenery Preservation Commission, I would still be inclined to see him as recreating a New Zealand bush scene rather than a British woodland.

86 Robyn Longhurst, 'Plots, plants and paradoxes; contemporary domestic gardens in Aotearoa/New Zealand,' Social and Cultural Geography 7 (2006): 589, doi.org/10.1080/14649360600825729. 
This text is taken from International Review of Environmental History, Volume 3, Issue 1, 2017, edited by James Beattie, published 2017 by ANU Press, The Australian National University, Canberra, Australia. 